\title{
Tumor necrosis is an important hallmark of aggressive endometrial cancer and associates with hypoxia, angiogenesis and inflammation responses
}

\author{
Geir Bredholtt ${ }^{1, *}$, Monica Mannelqvist ${ }^{1,}{ }^{*}$, Ingunn M. Stefansson ${ }^{1,2}$, Even Birkeland ${ }^{1}$, \\ Trond Hellem B $\sigma^{1,3}$, Anne M. Øyan ${ }^{4,5}$, Jone Trovik, \\ Jonassen ${ }^{3}$, Helga B. Salvesen ${ }^{5,6}$, Elisabeth Wik ${ }^{1,2}$, Lars A. Akslen ${ }^{1,2}$ \\ ${ }^{1}$ Centre for Cancer Biomarkers CCBIO, Department of Clinical Medicine, Section for Pathology, University of Bergen, Bergen, \\ Norway \\ ${ }^{2}$ Department of Pathology, Haukeland University Hospital, Bergen, Norway \\ ${ }^{3}$ CCBIO, Department of Informatics, University of Bergen, Bergen, Norway \\ ${ }^{4}$ Department of Microbiology, Haukeland University Hospital, Bergen, Norway \\ ${ }^{5}$ Center for Cancer Biomarkers CCBIO, Department of Clinical Science, University of Bergen, Norway \\ ${ }^{6}$ Department of Gynecology and Obstetrics, Haukeland University Hospital, Bergen, Norway \\ *These authors have contributed equally to this work \\ Correspondence to: \\ Lars A. Akslen, e-mail: lars.akslen@uib.no \\ Keywords: necrosis, hypoxia, angiogenesis, inflammation, gene signatures \\ Received: June 11,2015 Accepted: October 02, 2015 \\ Published: October 14, 2015
}

\section{ABSTRACT}

Aims: Tumor necrosis is associated with aggressive features of endometrial cancer and poor prognosis. Here, we investigated gene expression patterns and potential treatment targets related to presence of tumor necrosis in primary endometrial cancer lesions.

Methods and Results: By DNA microarray analysis, expression of genes related to tumor necrosis reflected multiple tumor-microenvironment interactions like tissue hypoxia, angiogenesis and inflammation pathways. A tumor necrosis signature of 38 genes and a related patient cluster (Cluster I, $67 \%$ of the cases) were associated with features of aggressive tumors such as type II cancers, estrogen receptor negative tumors and vascular invasion. Further, the tumor necrosis signature was increased in tumor cells grown in hypoxic conditions in vitro. Multiple genes with increased expression are known to be activated by HIF1A and NF-kB.

Conclusions: Our findings indicate that the presence of tumor necrosis within primary tumors is associated with hypoxia, angiogenesis and inflammation responses. HIF1A, NF-kB and PI3K/mTOR might be potential treatment targets in aggressive endometrial cancers with presence of tumor necrosis.

\section{INTRODUCTION}

Tumor hypoxia is an important feature of aggressive cancers [1], and as a morphologic marker, necrosis is known to be associated with poor prognosis in a variety of tumors [2-5]. In endometrial cancer, necrosis is related to increased tumor cell proliferation, high FIGO stage, and reduced disease-specific survival [6-8]. We previously found that necrosis was associated with activated angiogenesis, reduced vascular maturation and presence of vascular invasion, suggesting a link between necrosis, tumorvascular interactions and metastatic spread [9]. In breast tumors, necrosis has been related to high-grade disease, increased tumor size, estrogen receptor negative status, high microvessel density, and macrophage infiltration $[3,10,11]$.

Hypoxic tumor cells surrounding necrotic tissue may represent areas of dedifferentiation and development or selection of increasingly malignant cells [12]. In tumors, inflammatory cells tend to accumulate within necrotic foci [13], and degraded tumor cells are known to release proinflammatory cytokines that may stimulate angiogenesis 
and cancer progression [14]. Further, angiogenic factors are secreted by tumor associated macrophages in such areas [15]. It appears that hypoxia promote high-grade tumor features [16], and necrosis has been associated with tumor progression and increased resistance to radiation and chemotherapy $[17,18]$.

Here, we explored differential gene expression patterns and potential treatment targets associated with tumor necrosis in endometrial cancers. Our findings indicate that necrosis and tumor gene expression patterns are associated with hypoxia, inflammation and angiogenesis networks.

\section{RESULTS}

\section{Tumor necrosis is associated with aggressive clinico- pathologic features and reduced patient survival}

In Series I $(n=57)$, tumor necrosis (present in $61 \%$ of the tumors) was associated with aggressive features such as non-endometrioid subtype, histologic grade 3 and FIGO stage III/IV (Table 1). Presence of necrosis was correlated to vascular invasion and to the tumor subgroup classified as aggressive by a gene expression signature published by Salvesen et al. [19] In Series II $(n=286)$, tumor necrosis (present in 58\%) was associated with similar aggressive features and advanced stage (Table 1), and necrosis was associated with decreased patient survival in both series (Figure 1). No significant differences were found between Series I and II with respect to distribution of basic clinicopathologic factors (data not shown).

\section{Tumor necrosis and associated gene expression patterns}

Analysis by SAM with respect to tumor necrosis indicated that 25 genes were significantly up-regulated and 13 genes down-regulated in cases with presence of necrosis (fold change $\geq 2$; false discovery rate 0.06) (Table 2). 10 of these genes generated from microarray analysis were validated by qPCR. The two methods showed strongly and significantly correlated expression values (data not shown). From hierarchical clustering of these 38 genes (Pearson correlation as similarity measure, average linkage WPGMA), one of the two main clusters were significantly associated with tumor necrosis $(p=0.0001)$ as well as other aggressive clinico-pathological characteristics (Supplementary Table S1, Figure 2). High tumor necrosis signature (TNS) (by median value) showed a trend for reduced survival, $p=0.058$ (Supplementary Figure S1).

Using the 38 SAM genes in a diagonal linear discriminant predictor, the correct classification rate by LOOCV was $75 \%$. Using a condensed and fixed gene subset of 13 of the 38 genes as predictor ( 7 up-regulated and 6 down-regulated genes marked in Table 2) gave $87 \%$ correct prediction.

\section{Tumor necrosis is associated with markers of hypoxia}

Gene set enrichment analysis (GSEA) indicates tumor necrosis to be associated with several data sets related to hypoxia, angiogenesis and inflammation (Table 3). Among genes differentially expressed between tumor samples with and without necrosis, a substantial number of hypoxia-related genes were found to be up-regulated, such as IL6, CXCL8 (IL8), SERPINE1 as well as genes involved in glycolysis (SLC2A3, LDHA) (Table 2 and Supplementary Table S2). Also, gene ontology (GO) analysis showed significant enrichment of the biological process glycolysis $(p<0.0001)$. Several hypoxia-induced genes are included in this GO category (data not shown).

In our data, two of the main subgroups from hierarchical clustering of the hypoxia gene signatures from Manola and Nuyten [20,21], were significantly associated with tumor necrosis ( $p=0.013$ and $p=0.0009$, respectively) (Figure $3 \mathrm{~b}$ and $3 \mathrm{~d}$ ). Further, three other gene signatures related to hypoxia were mapped to our data set [22-24], and correlations between our necrosis signature score and the applied hypoxia signature scores were explored. The tumor necrosis signature (TNS) was significantly correlated to all hypoxia signatures with $\mathrm{R}_{\mathrm{s}}$ from $0.52-0.72$ (Figure $4 \mathrm{~A}$ ).

The 38-gene necrosis signature was investigated in endometrial cancer cell lines exposed to hypoxic conditions. The necrosis signature showed a significantly higher score among the 8 biological replicates under hypoxia compared to normoxic conditions, reflecting tumor cell intrinsic responses (Wilcoxon Signed Rank test, related samples, $p=0.05$ ) (Supplementary Table S3).

\section{Exploration of potential treatment targets in tumors with presence of necrosis}

Genes differentially expressed between tumors with and without necrosis was applied in Connectivity Map analysis. Among 1309 small molecules represented in Connectivity Map, the drug signatures of Emetine and Cephaeline were among the top ranked drug signatures negatively correlated with the tumor necrosis signature, and may thus be potential inhibitors of tumor samples with necrosis (Table 4). These drugs have been reported to inhibit activation of HIF1A [25, 26], supporting HIF1A to play a role in tumors with necrosis. Also, signatures of $\mathrm{PI} 3 \mathrm{~K} / \mathrm{mTOR}$ inhibitors were negatively correlated to the necrosis signature (Table 4). These drugs have been shown to inhibit HIF1A [27, 28], and PI3K and mTOR are here suggested as potential targets in cases with tumor necrosis.

\section{Tumor necrosis is associated with markers of angiogenesis}

Both in Series I $(n=57)$ and Series II $(n=286)$, necrosis was associated with vascular invasion (Table 1). 
Table 1: Presence or absence of necrosis in Series I $(N=57)$ and II $(N=286)$ and associations with clinico-pathologic features

\begin{tabular}{|c|c|c|c|c|c|c|c|}
\hline & \multicolumn{3}{|c|}{ Series I } & \multicolumn{3}{|c|}{ Serie II } \\
\hline & & $\begin{array}{c}\text { Necrosis - } \\
n(\%)\end{array}$ & $\begin{array}{c}\text { Necrosis }+ \\
n(\%)\end{array}$ & $p$-value* & $\begin{array}{c}\text { Necrosis - } \\
n(\%)\end{array}$ & $\begin{array}{c}\text { Necrosis }+ \\
n(\%)\end{array}$ & $p$-value* \\
\hline \multirow[t]{2}{*}{ Histologic type } & Endometrioid & $22(43)$ & $29(57)$ & 0.04 & $114(44)$ & $143(56)$ & 0.005 \\
\hline & $\begin{array}{l}\text { Non- } \\
\text { endometrioid }\end{array}$ & $0(0)$ & $6(100)$ & & $5(17)$ & $24(83)$ & \\
\hline \multirow[t]{2}{*}{$\begin{array}{l}\text { Histologic } \\
\text { grade }\end{array}$} & Grade 1 and 2 & $21(48)$ & $23(52)$ & 0.009 & $98(55)$ & $79(45)$ & $<0.0001$ \\
\hline & Grade 3 & $1(8)$ & $12(92)$ & & $21(19)$ & $88(81)$ & \\
\hline \multirow[t]{2}{*}{$\begin{array}{l}\text { Type II cancer } \\
{[77]}\end{array}$} & No & $21(52)$ & $19(48)$ & 0.001 & - & - & - \\
\hline & Yes & $1(6)$ & $16(94)$ & & - & - & \\
\hline \multirow[t]{2}{*}{$\begin{array}{l}\text { Estrogen } \\
\text { receptor }\end{array}$} & Positive & $21(50)$ & $21(50)$ & 0.003 & $65(52)$ & $59(48)$ & 0.0005 \\
\hline & Negative & $1(7)$ & $14(93)$ & & $44(31)$ & $99(69)$ & \\
\hline \multirow[t]{2}{*}{$\begin{array}{l}\text { Progesterone } \\
\text { receptor }^{\dagger}\end{array}$} & Positive & $20(44)$ & $25(56)$ & 0.079 & $49(53)$ & $44(47)$ & 0.011 \\
\hline & Negative & $2(17)$ & $10(83)$ & & $62(36)$ & $108(64)$ & \\
\hline \multirow[t]{2}{*}{ Mitoses } & Low & $19(45)$ & $23(55)$ & NS & $105(49)$ & $111(51)$ & $<0.001$ \\
\hline & High & $3(20)$ & $12(80)$ & & $14(20)$ & $56(80)$ & \\
\hline \multirow[t]{2}{*}{$\begin{array}{l}\text { Vascular } \\
\text { invasion }\end{array}$} & Absent & $20(57)$ & $15(43)$ & $<0.001$ & $95(52)$ & $88(48)$ & 0.013 \\
\hline & Present & $2(9)$ & $20(91)$ & & $24(23)$ & $79(77)$ & \\
\hline \multirow[t]{2}{*}{$\begin{array}{l}\text { Myometrial } \\
\text { infiltration }\end{array}$} & $<50 \%$ & $15(50)$ & $15(50)$ & 0.062 & $56(48)$ & $61(52)$ & 0.004 \\
\hline & $\geq 50 \%$ & 7 (29) & $20(71)$ & & $22(26)$ & $62(74)$ & \\
\hline \multirow[t]{2}{*}{ FIGO stage } & $\mathrm{I} / \mathrm{II}$ & $22(46)$ & $26(54)$ & 0.01 & $16(29)$ & $39(71)$ & 0.039 \\
\hline & III/IV & $0(0)$ & $9(100)$ & & $102(44)$ & $128(56)$ & \\
\hline \multirow[t]{2}{*}{$\begin{array}{l}\text { Aggressive } \\
\text { cluster [78] }\end{array}$} & No & $16(55)$ & $13(45)$ & 0.009 & - & - & - \\
\hline & Yes & $6(21)$ & $22(79)$ & & - & - & \\
\hline
\end{tabular}

${ }^{*}$ Chi-sq uare test, two-sided

Cut-point median

Cut-point upper quartile

`Type I cancers are highly and moderately differentiated tumors, have superficial invasion of the myometrium, have high sensitivity to progestogens and favorable prognosis. Type II cancers are poorly differentiated tumors, have deeper invasion of tumor into the myometrium, higher frequency of metastatic spread into the pelvic lymph nodes, decreased sensitivity to progestogens and less favorable prognosis

Several angiogenesis-related genes like MMP1, MMP3, SFRP2, CXCL8, SERPINE1 and TNFAIP6 were upregulated in tumors with necrosis, as identified among genes differentially expressed between tumor samples with and without necrosis (Table 2 and Supplementary Table S2).
Hierarchical clustering of the genes from the endothelial signature [24] in our data set gave a significant association between the resulting two clusters and necrosis status in the tumors $(p=0.015)$ (Figure 3c). Also, clustering of the wound response gene signature [29] 

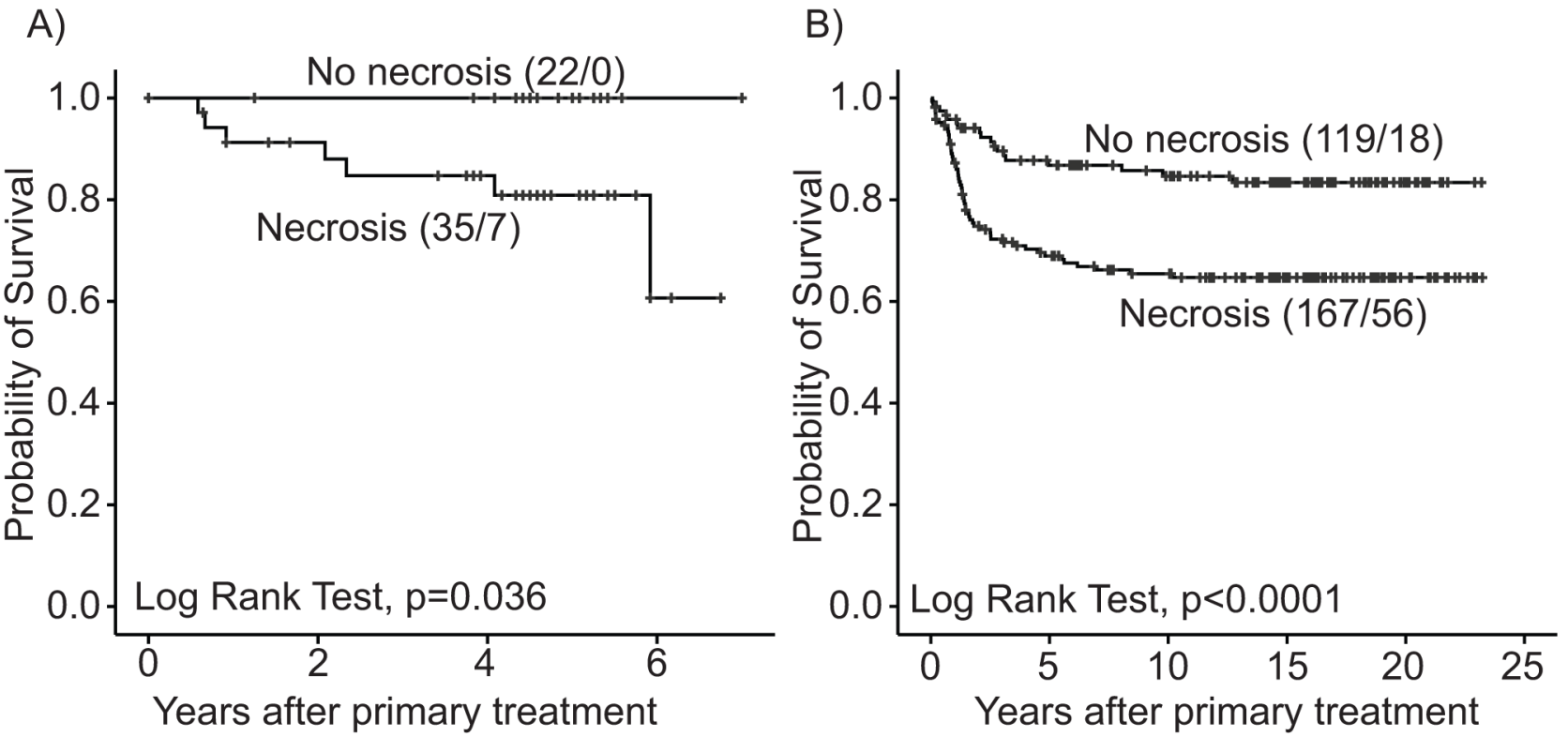

Figure 1: Estimated survival among endometrial carcinoma patients according to tumor necrosis. $\mathbf{A}$. Series $\mathrm{I}(N=57)$ and B. Series II $(N=286)$, for each category, total number of cases/events is given.

showed a significant association between the resulting two clusters and tumor necrosis $(p=0.009)$ (Figure 3a). Two other gene signatures related to angiogenesis were mapped to our data set [29-31]. The correlations between these and the necrosis signature were explored, and the necrosis signature score was significantly correlated to both signature scores, with Spearman correlation coefficients, $\mathrm{R}_{\mathrm{s}}$, of 0.70 and 0.44 , respectively (Figure $4 \mathrm{~b}$ ). GSEA analysis showed several datasets related to angiogenesis to be up-regulated in samples with necrosis (Table 3).

In addition to gene expression analysis, the tumors in Series II have been investigated by IHC for the angiogenic factors VEGF-A, VEGF-C, VEGF-D and bFGF. Presence of tumor necrosis was significantly associated with increased expression of these angiogenic markers (Supplementary Table S4), supporting a relation between tumor necrosis and angiogenesis.

\section{Tumor necrosis is associated with markers of inflammation}

By supervised analysis we found that multiple genes related to inflammatory processes and immune responses were significantly up-regulated in tumors with necrosis, such as chemokines (CXCL8, CCL20, CXCL1), metalloproteinases (MMP1, MMP3, MMP9) and proinflammatory genes (IL1B, PTGS2). In addition, numerous immunoglobulin genes were up-regulated in necrotic tumors (Table 2, Supplementary Table S2).

GO analysis showed significant enrichment $(p<0.0001)$ of gene sets reflecting various immune related responses as natural killer cell mediated immunity, immunity and defense, and granulocyte-mediated immunity (data not shown). By GSEA, several gene sets involved in inflammatory processes, among them different NF- $\mathrm{KB}$ gene sets, were enriched in tumors with necrosis (Table 3). The analysis indicated that genes under control of NF- $\mathrm{kB}$, genes induced in activated dendritic cells, genes up-regulated in activated neutrophils, and genes induced by CCL20, IL1B and CXCL1, were up-regulated (Supplementary Table S2).

$\mathrm{NF}-\kappa \mathrm{B}$ related genes and a dendritic cell inflammation signature were mapped to our data set $[32,33]$. The necrosis signature score was significantly correlated to both the NF$\kappa B$ genes and the dendritic inflammation signature with $R_{s}$ of 0.73 and 0.62 , respectively (Figure 4C).

Series II had information on lymphocytic infiltration, and the association with necrosis was investigated. Tumors with presence of necrosis showed significant association with perivascular lymphocytic infiltration (Supplementary Table S5). In subgroup analyses, this association was present among endometrioid carcinomas only $(p=0.001)$, and not among non-endometroid tumors ( $p=\mathrm{NS}$ ) (data not shown).

\section{Tumor necrosis is associated with estrogen receptor negative tumors}

Both Series I and II show tumor necrosis to be associated with eswwtrogen receptor negative tumors (Table 1). GSEA analysis supports this, showing estrogen responsive gene sets to be related to necrosis (Table 3).

\section{DISCUSSION}

Tumor hypoxia, an important hallmark of aggressive cancers [1], is related to a more stimulatory 
Table 2: Genes differentially expressed in samples with tumor necrosis $(n=35)$ compared with non-necrotic tumors $(n=22)$ tissues

\begin{tabular}{|c|c|c|}
\hline Gene symbol & Gene name & Fold Change \\
\hline \multicolumn{3}{|c|}{ Up-regulated genes } \\
\hline MMP1 & Matrix metallopeptidase 1 (interstitial collagenase) & 7.2 \\
\hline SFRP2 & Secreted frizzled-related protein 2 & 5.6 \\
\hline IGLV1-51 & Immunoglobulin lambda variable $1-51$ & 4.1 \\
\hline $\mathrm{CXCL}^{\mathrm{P}}$ & Chemokine (C-X-C motif) ligand 8 & 3.8 \\
\hline MAGEA1 & Melanoma antigen family A1 & 3.3 \\
\hline IGKV4-1 & Immunoglobulin kappa variable 4-1 & 3.0 \\
\hline TNFAIP6 ${ }^{\mathrm{P}}$ & Tumor necrosis factor, alpha-induced protein 6 & 3.0 \\
\hline IGKV6-21 & Immunoglobulin kappa variable 6-21 & 3.0 \\
\hline HCAR $^{\text {P }}$ & Hydroxycarboxylic acid receptor 3 & 2.7 \\
\hline IL1RN & Interleukin 1 receptor antagonist & 2.6 \\
\hline IGLV5-37 & Immunoglobulin lambda variable 5-37 & 2.6 \\
\hline IGHA1 & Immunoglobulin heavy constant alpha 1 & 2.6 \\
\hline A_23_P113056 & & 2.5 \\
\hline MT2A ${ }^{P}$ & Metallothionein 2A & 2.5 \\
\hline A_23_P32583 & & 2.5 \\
\hline $\mathrm{BCL} 2 \mathrm{~A} 1^{\mathrm{P}}$ & BCL2-related protein A1 & 2.4 \\
\hline SIX1 $^{\mathrm{P}}$ & SIX homeobox 1 & 2.4 \\
\hline A_23_P84795 & & 2.4 \\
\hline IGLV3-19 & Immunoglobulin lambda variable 3-19 & 2.3 \\
\hline IGHA1 & Immunoglobulin heavy constant alpha 1 & 2.3 \\
\hline IGKV1-33 & Immunoglobulin kappa variable $1-33$ & 2.3 \\
\hline A_23_P61039 & & 2.3 \\
\hline G0S2 & G0/G1switch 2 & 2.2 \\
\hline IGHV3-11 & Immunoglobulin heavy variable $3-11$ & 2.1 \\
\hline IGHV3-48 & Immunoglobulin heavy variable $3-48$ & 2.1 \\
\hline \multicolumn{3}{|c|}{ Down-regulated genes } \\
\hline DEFA6 & defensin, alpha 6 , Paneth cell-specific & -9.2 \\
\hline $\mathrm{CST}^{\mathrm{P}}$ & Cystatin SN & -3.3 \\
\hline $\mathrm{OGN}^{\mathrm{P}}$ & Osteoglycin (osteoinductive factor, mimecan) & -3.0 \\
\hline SERPINA5 ${ }^{\text {P }}$ & $\begin{array}{l}\text { Serpin peptidase inhibitor, clade A (alpha-1 antiproteinase, antitrypsin), } \\
\text { member } 5\end{array}$ & -2.8 \\
\hline MAMDC2 & MAM domain containing 2 & -2.7 \\
\hline ANGPTL1 & Angiopoietin-like 1 & -2.6 \\
\hline $\mathrm{ALDH} 1 \mathrm{~A} 2^{\mathrm{P}}$ & Aldehyde dehydrogenase 1 family, member A2 & -2.4 \\
\hline DPP6 & Dipeptidyl-peptidase 6 & -2.3 \\
\hline
\end{tabular}




\begin{tabular}{|c|c|c|}
\hline Gene symbol & Gene name & Fold Change \\
\hline MIR503HG & MIR503 host gene (non-protein coding) & -2.2 \\
\hline HAND2 & Heart and neural crest derivatives expressed 2 & -2.2 \\
\hline SLC25A27 ${ }^{\mathrm{P}}$ & Solute carrier family 25 , member 27 & -2.0 \\
\hline ADHFE $^{\text {P }}$ & Alcohol dehydrogenase, iron containing, 1 & -2.0 \\
\hline $\mathrm{CDO} 1$ & Cysteine dioxygenase, type I & -2.0 \\
\hline
\end{tabular}

$P=$ predictor genes

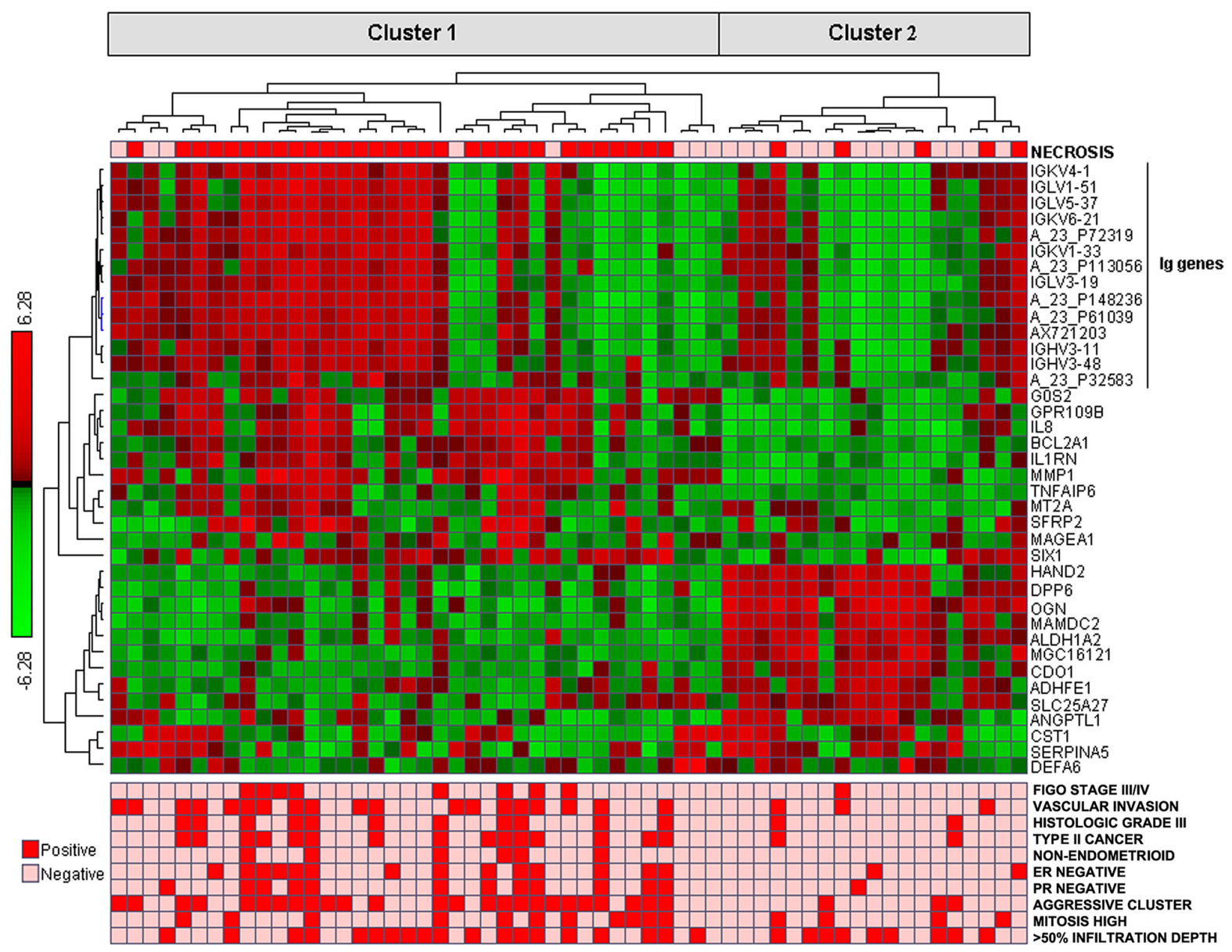

Figure 2: Cluster diagram of genes from SAM analysis; 38 genes differentially expressed between necrosis+ and necrosis-tumors In the lower part of the panel, related clinico-pathologic characteristics are shown.

microenvironment with increased angiogenesis and inflammation as co-existing responses [34, 35]. The presence of tumor necrosis, a morphologic marker of hypoxia, is associated with impaired prognosis in multiple malignant tumors [3-5]. Our previous studies have indicated a relationship between tumor necrosis and activated angiogenesis in endometrial carcinomas, as we found significantly increased vascular proliferation in tumors with necrosis [7]. However, less is known about gene expression programs and signaling pathways related to tumor necrosis in patient samples. In this study, we identified a 38-gene signature related to tumor necrosis in endometrial cancers. The necrosis gene signature showed associations with multiple features like hypoxia, angiogenesis and inflammation, and potentially novel treatment targets in the most aggressive tumors were suggested.

\section{Tumor necrosis and hypoxia}

It is well established that tumor necrosis is initiated by tissue hypoxia during tumor progression due to rapid tumor growth and inadequate blood supply [36]. In line 
Table 3: GSEA analysis showing gene sets related to the themes hypoxia, angiogenesis, inflammation, prognosis and ER status

\begin{tabular}{|c|c|c|c|}
\hline Description of gene set & Gene set size & Genes enriched & FDR $(\%)$ \\
\hline \multicolumn{4}{|l|}{ Gene sets related to hypoxia } \\
\hline $\begin{array}{l}\text { Combination of all hypoxia target gene sets in the GSEA } \\
\text { MSigDB database* }\end{array}$ & 152 & $67(44 \%)$ & 5.6 \\
\hline Genes upregulated in hypoxic macrophages [79] & 30 & $13(43 \%)$ & 6.5 \\
\hline GO:0006096 and GO:0019642: Glycolysis (homo sapiens) ${ }^{\dagger}$ & 36 & $17(47 \%)$ & 7.1 \\
\hline Genes upregulated in hypoxic epithelial cells [80] & 51 & $23(45 \%)$ & 7.9 \\
\hline $\begin{array}{l}\text { Gene expression signature of melanoma spheroids with a } \\
\text { necrotic core compared to monolayer culture [81] }\end{array}$ & 72 & $44(61 \%)$ & 8.1 \\
\hline Genes involved in glycolysis & 29 & $17(51 \%)$ & 9.1 \\
\hline
\end{tabular}

Gene sets related to angiogenesis

\begin{tabular}{|l|c|c|c|}
\hline $\begin{array}{l}\text { Extracellular matrix molecules related to endothelial cell } \\
\text { activation }\end{array}$ & 33 & $12(36 \%)$ & 6.2 \\
\hline $\begin{array}{l}\text { HUVEC stimulated with a combination of HGF and VEGF } \\
{[82]}\end{array}$ & 178 & $75(42 \%)$ & 7.8 \\
\hline Genes upregulated by EGFR1 ${ }^{\S}$ & 135 & $74(55 \%)$ & 9.5 \\
\hline Genes upregulated by TGF- $\beta^{\S}$ & 646 & $214(33 \%)$ & 17.0 \\
\hline
\end{tabular}

Gene sets related to stress and inflammatory processes

\begin{tabular}{|c|c|c|c|}
\hline $\mathrm{NF}-\kappa \mathrm{B}$ genes and confirmed targets [83] & 46 & $24(52 \%)$ & 5.8 \\
\hline $\begin{array}{l}\text { Human genes with confirmed promoter binding sites for } \\
N F-\kappa B \|\end{array}$ & 77 & $39(51 \%)$ & 6.5 \\
\hline Genes upregulated by $\mathrm{IL}_{1}^{\S}$ & 132 & $59(45 \%)$ & 6.9 \\
\hline $\begin{array}{l}\text { Genes upregulated by IL1B in human endometrial stromal } \\
\text { cells [84] }\end{array}$ & 17 & $14(82 \%)$ & 7.3 \\
\hline Genes upregulated by IL5 $5^{\S}$ & 108 & $43(40 \%)$ & 7.3 \\
\hline Confirmed NF- $\kappa \mathrm{B}$ target genes ${ }^{\dagger \dagger}$ & 185 & $83(45 \%)$ & 8.0 \\
\hline
\end{tabular}

Gene sets related to prognosis and estrogen receptor

Genes upregulated in breast cancers with poor prognosis [85]

70 gene signature associated with poor prognosis in breast cancer [85]

Genes upregulated in estrogen receptor negative breast cancers [85]

Human estrogen responsive genes [86]

\begin{tabular}{|c|c|c|c|}
\hline 129 & $64(50 \%)$ & 6.1 \\
\hline & 45 & $23(51 \%)$ & 6.2 \\
\hline & 878 & $413(47 \%)$ & 11.4 \\
\hline
\end{tabular}

Gene sets in the different groups are ranked according to the false discovery rate (FDR)

*http://www.broad.mit.edu/gsea/msigdb/

thttp://amigo.geneontology.org/

"http://www.pantherdb.org/

thttp://www.superarray.com

§http://www.netpath.org

"http://bioinfo.lifl.fr/NF-KB/

thttp://www.bu.edu/nf-kb/gene-resources/target-genes/ 


\section{A) Wound Response Signature}

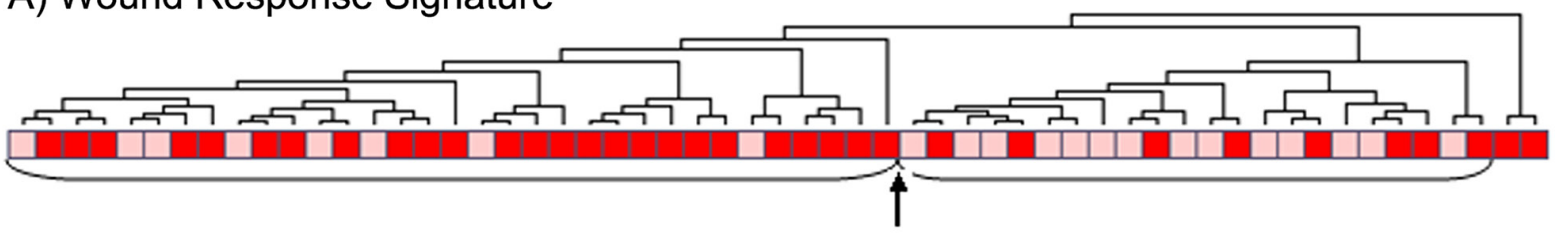

B) Hypoxia Gene Signature (endothelial cells)

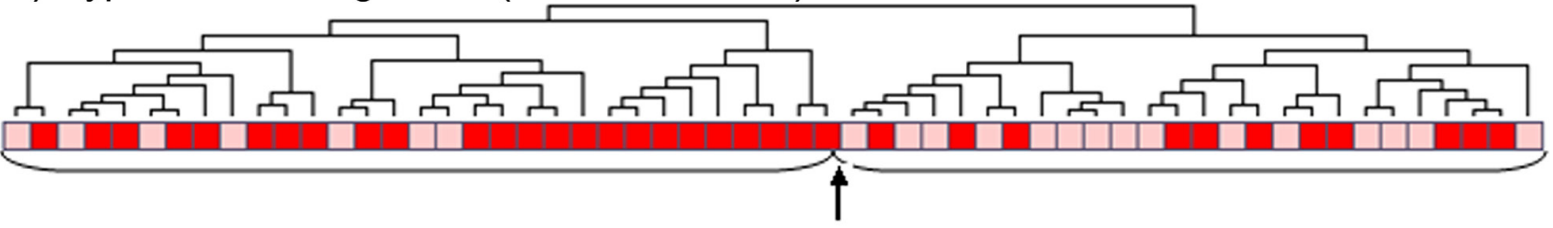

C) Endothelial Gene Signature

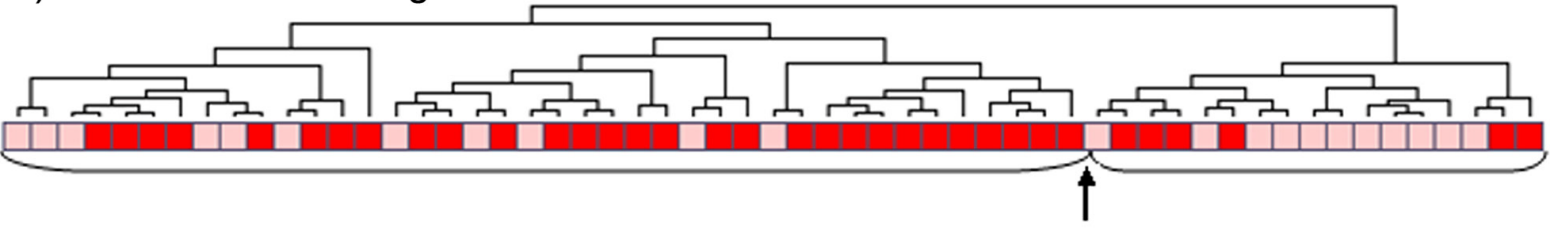

D) Hypoxia Gene Signature (breast tumors)

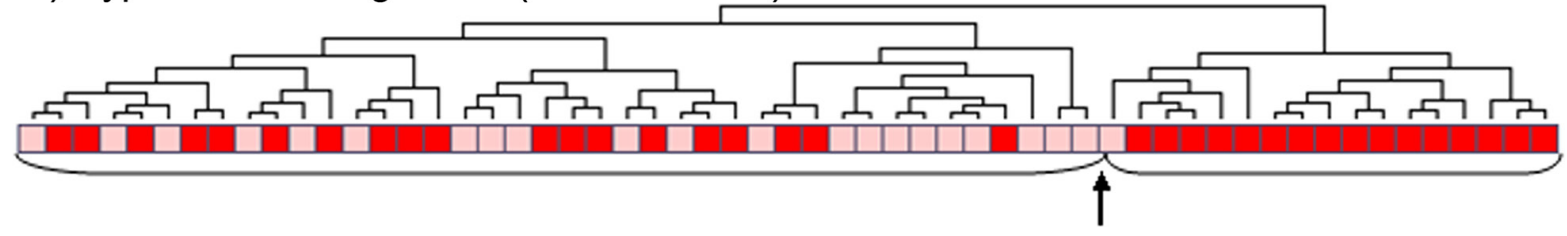

Figure 3: Clustering of tumors with (red) or without (pink) tumor necrosis using different gene signatures. A. the wound response signature of 389 genes [29], $p=0.003$, B. differentially expressed genes to hypoxia by HIF1A in vascular endothelial cells [20], 460 genes, $p=0.007, \mathbf{C}$. the endothelial gene signature of 28 genes [24], $p=0.008$ and $\mathbf{D}$. the hypoxia gene signature [21], 101 genes, $p=0.0009$. (The arrow points to the border between two main clusters).

with this, we found that a panel of endometrial cancer cell lines grown under hypoxic conditions showed some upregulation of the tumor necrosis signature derived from clinical samples, reflecting tumor cell intrinsic responses. Hypoxia is a marker of more aggressive tumors [18, $37,38]$, and tumor necrosis was significantly associated with features such as high histologic grade, vascular invasion by tumor cells and reduced survival. In relation to treatment, hypoxia is thought to be a predictive marker for radiotherapy and chemotherapy response, since low oxygen levels are associated with less effective radiation treatment and reduced drug delivery $[35,39,40]$.

In our study, drug signatures of Emetine and Cephaeline, known to inhibit HIF1A [25], were negatively associated with the tumor necrosis signature, further supporting hypoxia as an important feature of aggressive endometrial cancer. Also, PI3K/mTOR inhibitors could represent potential treatment for necrosis positive tumors according to our findings.

\section{Tumor necrosis and angiogenesis}

We found that tumor necrosis and the necrosis related gene signature were associated with different angiogenic responses. Thus, tumors with necrosis were significantly linked to increased expression of multiple angiogenesis markers, such as IL1B, CXCL8, CXCL1, MMP1, MMP3, MMP9, SFRP2, PTGS2, BCL2A1, STC1, SOD2, SERPINE1, TNFRSF12A, FN1, ANGPTL4, ICAM1, and PTTG1. Common to the majority of these angiogenesis supporting genes is that they are induced by hypoxia and under transcriptional control of either HIF1A or NF-kB [41].

In contrast, HAND2 was found to be down-regulated in tumors with necrosis. A previous study demonstrated that HAND2 is required for proper vascular development, and HAND2 knockout mice demonstrated embryonic lethality [42]. Endothelial differentiation was unaltered, but endothelial cell patterning and smooth muscle cell differentiation was disrupted leading to abnormal vascular development. These findings suggest that HAND2 inactivation may lead to the development of dysfunctional and leaky vessels commonly seen in malignant tumors [42]. Also, a recent study on endometrial cancers showed HAND2 knock-out mice to get more pre-neoplastic alterations [43].

SFRP2 was especially increased among tumors with necrosis, being more than five-fold up-regulated. 
A) Hypoxia related signatures
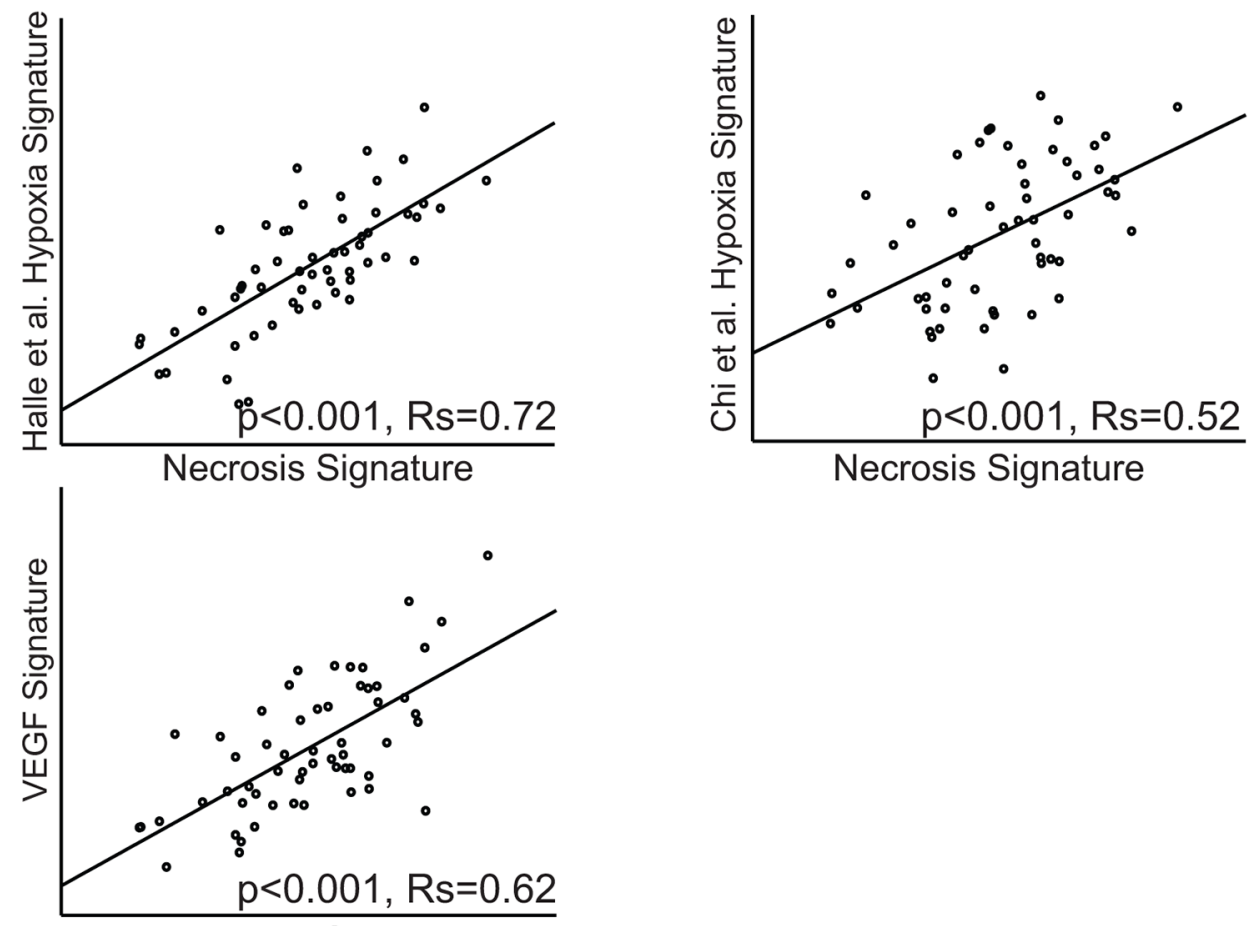

Necrosis Signature

B) Angiogenesis related signatures
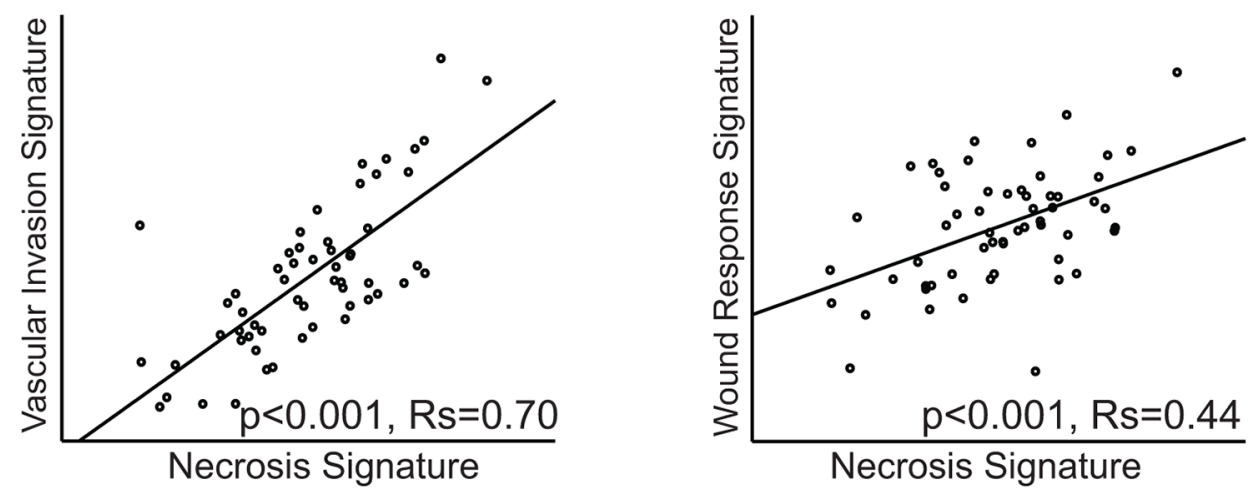

C) Inflammation related signatures
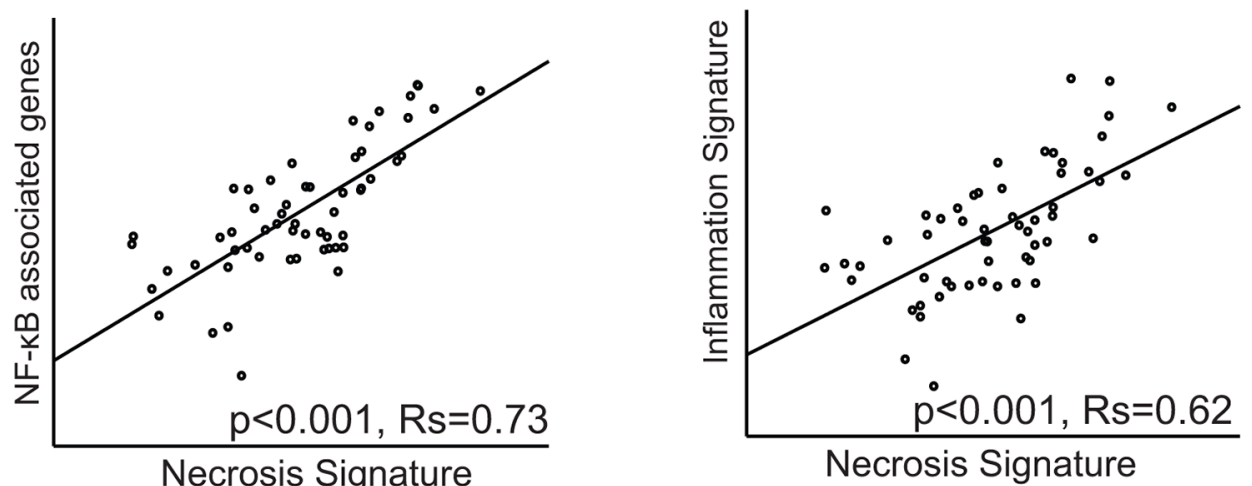

Figure 4: Correlation between the necrosis signature and signatures related to $A$. hypoxia [22, 23, 74], B. angiogenesis $[29,31]$ and $C$. inflammation $[32,33]$. The Spearman rank correlation test was used for bivariate correlations. 
Table 4: CMAP anlysis of 330 up-regulated genes $(p<0.024)$ and 390 down-regulated genes $(p<0.021)$ in necrotic tumors compared with non-necrotic tumor samples (according to $t$-test)

\begin{tabular}{|l|c|c|c|c|}
\hline \multicolumn{1}{l}{ Perturbagen } & \multicolumn{1}{c}{$\boldsymbol{n}$} & \multicolumn{1}{c}{ Enrichment } & \multicolumn{1}{c|}{$\boldsymbol{P}$} & Mechanism of action \\
\hline Emetine & 4 & -0.957 & $<0.0001$ & Inhibitor of protein synthesis \\
\hline LY-294002 & 61 & -0.595 & $<0.0001$ & Inhibitor of PI3Ks \\
\hline Sirolimus & 44 & -0.507 & $<0.0001$ & Inhibitor of mTOR \\
\hline Wortmannin & 18 & -0.605 & $<0.0001$ & Inhibitor of PI3Ks \\
\hline Quinostatin & 2 & -0.993 & 0.0002 & Inhibitor of PI3Ks \\
\hline Cephaeline & 5 & -0.788 & 0.0008 & Inhibitor of protein synthesis \\
\hline
\end{tabular}

The perturbagens negatively connected with the genes with $\boldsymbol{p}$-value $<0.001$

Recently, this protein was found to be overexpressed in the vasculature of $85 \%$ of human breast tumors and a novel stimulator of angiogenesis via a calcineurin dependent pathway [44]. Thus, tumor hypoxia might stimulate SFRP2 and trigger both NF-kB dependent pathways and multiple angiogenic factors $[44,45]$. Interestingly, SEMA3E was 2.3-fold down-regulated in necrotic tumors, and this protein has also been involved in vascular patterning [46]. SEMA3E overexpression in a tumor xenograft model dramatically decreased the metastatic potential [47].

HIF1A is one of the major mediators of hypoxia induced VEGF expression [48]. Here, we found that tumors with necrosis showed significantly increased expression of angiogenic factors VEGF-A, VEGF-C and VEGF-D. bFGF expression is reported to be increased during inflammation and in necrotic cells, and elevated levels have been associated with better response to chemotherapy [49, 50]. In our study, we found bFGF protein levels to be increased in tumors with necrosis.

\section{Tumor necrosis and inflammation}

Expression of NF-kB, a nuclear transcription factor involved in stress responses, is stimulated by tissue hypoxia [51]. Our data indicate that in cancers with necrosis, a substantial part of the up-regulated genes associated with inflammation is under transcriptional control of NF-kB. These include multiple factors such as CXCL8, CXCL1, MMP1, MMP9, VCAM1, ANGPTL4, ICAM1, and PLAU [52-54]. In support of this, a previous study indicated a potential role of NF-kB in endometrial cancer [55]. IL1B, an inducer of NF-kB [56, 57], was up-regulated two-fold, and significant enrichment of genes induced by IL1B was found by GSEA. The IL1 family itself is also under control of NF-kB [58], and this axis might represent a biological amplification mechanism. The inflammation amplifier reflect genes associated with cancer development [59], and several genes from the amplifiers were found up-regulated in necrotic tumors, like PTGS2, IL6, SERPINE1 and SOD2. Studies have reported high IL1 concentrations within the tumor microenvironment in association with aggressive tumors [60]. The correlation between NF-kB related genes and our necrosis signature support this.

\section{Tumor necrosis and estrogen receptor expression}

Estrogen signaling is important in the biology of endometrial cancer, and there are striking phenotypic differences between estrogen receptor positive and negative tumors [61]. Here, ER negative cancers were significantly associated with tumor necrosis. We observed by GSEA a significant enrichment of genes in tumors with necrosis that are also up-regulated in estrogen receptor negative breast cancers [16].

Loss of estrogen receptor expression is observed to activate NF-kB [62], and ESR1 and NF-kB are known to mutually antagonize each other [63]. Correspondingly, estrogen and progesterone receptors have the ability to block NF-kB activation [64]. It is not clear, however, whether NF- $\kappa \mathrm{B}$ activation is thus an intrinsic property of ER negative endometrial cancers, or is activated secondary to tumor necrosis, or a combination.

Thus, our findings derived from patient samples indicate that tumor necrosis is associated with multiple co-existing high-grade features and responses such as tumor angiogenesis and tumor inflammation. This might indicate a potential co-regulation of interacting tumor programs linked to hypoxia in these tumors. The findings are consistent in different analysis approaches. However, further studies are needed to expand on the mechanistic links that might be involved and treatable.

\section{CONCLUSION}

Presence of tumor necrosis was reflected by increased expression of multiple gene sets and pathways related to tumor-microenvironment interactions, such as tissue hypoxia, angiogenesis and inflammation, indicating complex cross-talk as well as potentially novel biomarkers and therapy targets. Tumor necrosis in endometrial cancers is associated with ER negative tumors and 
NF-kB activation. As indicated by our data, HIF1A, NF-kB and $\mathrm{PI} 3 \mathrm{~K} / \mathrm{mTOR}$ might be potential targets in aggressive endometrial cancers with presence of tumor necrosis.

\section{MATERIALS AND METHODS}

\section{Patient series}

Microarray and qPCR experiments were performed on a prospectively collected explorative series of fresh frozen specimens (Series I). Clinico-pathologic correlates and outcome were also studied in this series and in a retrospective series for validation (Series II). Series I: During 2001-2003, 57 cases of endometrial cancer (median age 63.0 years) were prospectively collected at the Department of Gynecology and Obstetrics, Haukeland University Hospital, University of Bergen, Norway, as previously described. [19] Series II: A population based series including all endometrial tumors diagnosed in Hordaland County (approximately 500,000 inhabitants, $10 \%$ of the Norwegian population) during 1981-1990, containing 316 formalin fixed and paraffin embedded tumors, was used as validation series [9].

\section{Pathology}

The following clinico-pathological variables were included for both series: histologic type, histologic grade, myometrial infiltration, estrogen and progesterone receptor status, mitotic count, necrosis, vascular invasion, and FIGO stage as previously reported [7, 9, 65]. Briefly, tumor necrosis was defined as areas of necrotic tumor cells immediately adjacent to viable tumor tissue [66]. The prospective series contained information on tumor category according to a 29 gene signature (cluster I and II) [19]. In addition, the retrospective series (Series II) had information on morphologic cancer type I/II [67], perivascular lymphocytic infiltration (PLI), tumor infiltrating lymphocytes (TIL) [68], and data on VEGF-A, VEGF-C, VEGF-D and bFGF expression by immunostaining [9].

\section{Follow-up}

For Series I, patients were followed from the time of primary surgery until September, 2008 or until death. Median follow-up time for survivors was 5.1 years (range $0.9-7.0$ years). All events (14 recurrences, 7 deaths from cancer) were recorded, and deaths due to other causes were censored in survival analyses. No patient was lost to follow-up. For Series II, of all 316 patients diagnosed with endometrial carcinoma in this population based series, there were 286 cases available for this study. Patients were followed from the time of primary surgery until death or last follow up, August 2004. Median follow-up time for the survivors was 17 years (range 10-23 years); 74 patients died from endometrial cancer. Cases without evaluable staining were excluded from the analysis of immunohistochemical markers.

\section{Microarray analysis}

Total RNA was extracted from biopsies with at least $50 \%$ (usually $>80 \%$ ) tumor content using the RNeasy minikit (Qiagen, Valencia, CA). Quality and yield were assessed by agarose electrophoresis, Agilent Bioanalyser 2100 (Agilent Technologies, Santa Clara, CA) and spectrophotometry. T7 RNA polymerase promoter containing cDNAs and $\mathrm{Cy} 3$ and $\mathrm{Cy} 5$ labeled cRNAs were generated and hybridized to Agilent $21 \mathrm{k}$ and $22 \mathrm{k}$ microarrays as described earlier [19, 69, 70]. All microarrays were scanned and features extracted using the Agilent Microarray Scanner Bundle (Agilent). Data was processed as described $[19,30]$. This dataset has been deposited in the GEO DataSets, GSE14860.

\section{Differential gene expression}

Significance analysis of microarrays (SAM) [71] was applied to look for genes differentially expressed between samples labeled necrotic positive $(\mathrm{N}+)$ and negative $(\mathrm{N}-)$. For the necrosis signature, a requirement of at least 2-fold change was applied together with a false discovery rate (FDR) of $\leq 0.06$. For hypothesis genes, collected from the literature, SAM with FDR $<0.2$ and fold change of 1.5 were used.

\section{Real-time PCR using taqman low density array format}

For validation of microrray data, mRNA levels of a subset of genes were analyzed using Taqman low density arrays (TLDA) for real-time qPCR (Applied Biosystems, Foster City, CA). cDNA synthesis and PCR protocols were performed as previously described [72]. To confirm gene expression data from microarray analysis, 10 of the 38 genes from the SAM signature were analyzed by qPCR.

\section{Predictors of necrosis using fixed gene sets}

Leave one out cross validation (LOOCV) was used to test the predictability of labels based on presence $(\mathrm{N}+)$ or absence $(\mathrm{N}-)$ of necrosis, using all except one sample as training data in each round. Cross validation was performed with the list of genes from SAM analysis fixed. Additionally, a condensed predictor was constructed from the SAM list genes in order to investigate if the same or better predictive power could be obtained with fewer genes in the predictive model. To construct this condensed predictor, techniques from machine learning called forward selection and backward elimination was applied [73]. Cross validation was then performed with 
this condensed predictor gene set. A diagonal linear discriminant was used as prediction model.

\section{Clustering of samples using thematic gene sets}

Different gene signatures related to hypoxia, angiogenesis and inflammation were used to investigate relations to tumor necrosis. The hypoxic gene sets were Manalo's signature containing differentially expressed genes in vascular endothelial cells exposed to hypoxia compared to normoxic endothelial cells [20] and Nuyten's hypoxia gene signature containing 123 genes generated from breast tumors [21]. For angiogenesis signatures, genes in the wound response (core serum response) signature [29] and in an endothelium signature [24] were mapped to our data set. As relatively few of the genes in the endothelial signature were found in our microarray data (28 out of 64), an expansion of the signature was carried out by including genes with significant correlation $(r>0.65)$ to one of the 28 signature genes. This gave an expanded signature of 468 genes.

Subsequently, the samples were clustered (hierarchical clustering, average linkage WPGMA, Pearson's correlation) based on the expression levels of the signature genes. The clustering of samples was tested for association to necrosis status $(\mathrm{N}+$ and $\mathrm{N}-)$.

\section{Gene signatures related to the necrosis signature}

Different signatures were used to investigate how the necrosis gene signature associates with hypoxia, angiogenesis and inflammation. Three hypoxia gene signatures have been used. Chi et al. constructed a gene signature showing the hypoxic response in mammary and renal tubular epithelial cells [22]. The hypoxia signature from Halle et al. was created for cervical cancer based on cell culture experiments [23]. The VEGF signature identifies a compact in vivo hypoxia signature highly expressed in metastatic breast tumors [74]. Two signatures in relation to angiogenesis were used: the vascular invasion signature constructed from endometrial tumors $[30,31]$ and the wound response signature [29]. For inflammation, a signature of NF- $\mathrm{kB}$-associated genes and an inflammation signature generated from dendritic cells were used [32, 33].

For correlation between signatures, summarized signature scores were calculated [75]. For the necrosis signature, the vascular invasion signature, the hypoxia signature from Chi et al. and the inflammation signature, summarized expression values for the down-regulated genes were subtracted from the sum of expression values for the up-regulated genes. For the wound response signature, a summary expression signature was generated for the activated genes. For the hypoxia signature from Halle et al., the VEGF signature and the NF-kB-regulated genes, a mean expression value from the expression values for the signature genes was calculated, as applied in the studies where the signatures were identified.

\section{Gene ontology (GO) analysis}

The gene expression tools on the PANTHER (Protein ANalysis THrough Evolutionary Relationships) website was applied to the complete gene set (http:// www.pantherdb.org/tools/genexAnalysis.jsp). Bonferroni correction for multiple testing was applied.

\section{Gene set enrichment analysis (GSEA)}

Our data set was investigated based on gene sets available through MSigDB (http://www.broadinstitute. $\mathrm{org} / \mathrm{gsea} / \mathrm{msigdb}$ ). Also, gene sets from the literature were constructed in GSEA and applied to our data set.

\section{Hypoxia stimulation of endometrial cancer cell lines}

Endometrial cancer cell lines KLE, RL95-2, AN3 CA, HEC-1-A (Manassas, Virginia, USA) and MFE-280, MFE-296, EFE-184 (German Collection of Microorganisms and Cell Cultures, DSMZ, Braunschweig, Germany) were cultured, without technical replicates, in media recommended by the suppliers. The cells were incubated for 18 hours in normoxia $\left(37^{\circ} \mathrm{C}, 5 \% \mathrm{CO}_{2}\right)$ or hypoxia $\left(37^{\circ} \mathrm{C}\right.$, $5 \% \mathrm{CO}_{2}, 1.5 \% \mathrm{O}_{2}$ ). The cells were harvested using 350 $\mu 1$ TRK Lysis Buffer per well from the E.Z.N.A. ${ }^{\circledR}$ Total RNA Kit I, and total RNA was purified in accordance with the manual (Omega Bio-Tek, Norcross, Georgia, USA). Quality and yield of the RNA samples were determined by agarose gel electrophoresis, Agilent Bioanalyzer 2100 and spectrophotometry. Gene expression was further investigated by microarray analysis as described above.

\section{Connectivity map}

The correlation between the global expression pattern for patients with tumor necrosis and drug signatures was assessed in Series I by the Connectivity Map database [76]. Genes differentially expressed between tumor subsets with necrosis present and absent were included in the signature as the basis for the analyses in Connectivity Map. This gene list included 330 up- and 390 down- regulated genes.

\section{Statistical analysis}

Statistical analyses were performed with the IBM SPSS Statistic version 21 (SPSS Inc., Chicago, IL). Linear associations between two continuous variables were evaluated by linear regression analysis and Spearman's correlation. Univariate survival analyses were performed using the Kaplan-Meier method (log-rank significance test), and necrosis score was dichotomized based on the median. Associations between different categorical variables were assessed by Pearson's chi-square test. Wilcoxon Signed Rank test was used for comparing two related samples. Probability of $<0.05$ was considered statistically significant. 


\section{ACKNOWLEDGMENTS AND FUNDING}

We thank Gerd Lillian Hallseth, Britt Edvardsen, Hua My Hoang, Beth Johannessen and Bendik Nordanger for excellent technical work.

\section{CONFLICTS OF INTEREST}

The authors declare no conflict of interest.

\section{GRANT SUPPORT}

This work was partly supported by the Research Council of Norway through its Centres of Excellence funding scheme, project number 223250. The study was also supported by other grants from the Research Council of Norway, the Helse Vest Research Fund, The National Program for Research in Functional Genomics in Norway (FUGE) of the Research Council of Norway, The Norwegian Cancer Society and the UroBergen Research Fund.

\section{REFERENCES}

1. Hanahan D, Weinberg RA. Hallmarks of cancer: the next generation. Cell. 2011; 144:646-674.

2. Edwards JG, Swinson DE, Jones JL, Muller S, Waller DA, O'Byrne KJ. Tumor necrosis correlates with angiogenesis and is a predictor of poor prognosis in malignant mesothelioma. Chest. 2003; 124:1916-1923.

3. Fisher ER, Anderson S, Redmond C, Fisher B. Pathologic findings from the National Surgical Adjuvant Breast Project protocol B-06. 10-year pathologic and clinical prognostic discriminants. Cancer. 1993; 71:2507-2514.

4. Lam JS, Shvarts O, Said JW, Pantuck AJ, Seligson DB, Aldridge ME, Bui MH, Liu X, Horvath S, Figlin RA, Belldegrun AS. Clinicopathologic and molecular correlations of necrosis in the primary tumor of patients with renal cell carcinoma. Cancer. 2005; 103:2517-2525.

5. Swinson DE, Jones JL, Richardson D, Cox G, Edwards JG, O'Byrne KJ. Tumour necrosis is an independent prognostic marker in non-small cell lung cancer: correlation with biological variables. Lung cancer. 2002; 37:235-240.

6. Scholten AN, Smit VT, Beerman H, van Putten WL, Creutzberg CL. Prognostic significance and interobserver variability of histologic grading systems for endometrial carcinoma. Cancer. 2004; 100:764-772.

7. Stefansson IM, Salvesen HB, Immervoll H, Akslen LA. Prognostic impact of histological grade and vascular invasion compared with tumour cell proliferation in endometrial carcinoma of endometrioid type. Histopathology. 2004; 44:472-479.

8. Seeber LM, Horree N, van der Groep P, van der Wall E, Verheijen RH, van Diest PJ. Necrosis related HIF-1alpha expression predicts prognosis in patients with endometrioid endometrial carcinoma. BMC cancer. 2010; 10:307.
9. Stefansson IM, Salvesen HB, Akslen LA. Vascular proliferation is important for clinical progress of endometrial cancer. Cancer Res. 2006; 66:3303-3309.

10. Jimenez RE, Wallis T, Visscher DW. Centrally necrotizing carcinomas of the breast: a distinct histologic subtype with aggressive clinical behavior. The American journal of surgical pathology. 2001; 25:331-337.

11. Leek RD, Landers RJ, Harris AL, Lewis CE. Necrosis correlates with high vascular density and focal macrophage infiltration in invasive carcinoma of the breast. British journal of cancer. 1999; 79:991-995.

12. Helczynska K, Kronblad A, Jogi A, Nilsson E, Beckman S, Landberg G, Pahlman S. Hypoxia promotes a dedifferentiated phenotype in ductal breast carcinoma in situ. Cancer Res. 2003; 63:1441-1444.

13. Scaffidi P, Misteli T, Bianchi ME. Release of chromatin protein HMGB1 by necrotic cells triggers inflammation. Nature. 2002; 418:191-195.

14. Vakkila J, Lotze MT. Inflammation and necrosis promote tumour growth. Nature reviews Immunology. 2004; 4:641-648.

15. Lewis $\mathrm{C}$, Murdoch $\mathrm{C}$. Macrophage responses to hypoxia: implications for tumor progression and anti-cancer therapies. Am J Pathol. 2005; 167:627-635.

16. Sadri N, Zhang PJ. Hypoxia-inducible factors: mediators of cancer progression; prognostic and therapeutic targets in soft tissue sarcomas. Cancers. 2013; 5:320-333.

17. Grivennikov SI, Greten FR, Karin M. Immunity, inflammation, and cancer. Cell. 2010; 140:883-899.

18. Hockel M, Vaupel P. Tumor hypoxia: definitions and current clinical, biologic, and molecular aspects. Journal of the National Cancer Institute. 2001; 93:266-276.

19. Salvesen HB, Carter SL, Mannelqvist M, Dutt A, Getz G, Stefansson IM, Raeder MB, Sos ML, Engelsen IB, Trovik J, Wik E, Greulich H, Bo TH, et al. Integrated genomic profiling of endometrial carcinoma associates aggressive tumors with indicators of PI3 kinase activation. Proc Natl Acad Sci U S A. 2009; 106:4834-4839.

20. Manalo DJ, Rowan A, Lavoie T, Natarajan L, Kelly BD, Ye SQ, Garcia JG, Semenza GL. Transcriptional regulation of vascular endothelial cell responses to hypoxia by HIF-1. Blood. 2005; 105:659-669.

21. Nuyten DS, Kreike B, Hart AA, Chi JT, Sneddon JB, Wessels LF, Peterse HJ, Bartelink H, Brown PO, Chang HY, van de Vijver MJ. Predicting a local recurrence after breast-conserving therapy by gene expression profiling. Breast Cancer Res. 2006; 8:R62.

22. Chi JT, Wang Z, Nuyten DS, Rodriguez EH, Schaner ME, Salim A, Wang Y, Kristensen GB, Helland A, BorresenDale AL, Giaccia A, Longaker MT, Hastie T, et al. Gene expression programs in response to hypoxia: cell type specificity and prognostic significance in human cancers. PLoS medicine. 2006; 3:e47.

23. Halle C, Andersen E, Lando M, Aarnes EK, Hasvold G, Holden M, Syljuasen RG, Sundfor K, Kristensen GB, Holm R, 
Malinen E, Lyng H. Hypoxia-induced gene expression in chemoradioresistant cervical cancer revealed by dynamic contrast-enhanced MRI. Cancer Res. 2012; 72:5285-5295.

24. Ho M, Yang E, Matcuk G, Deng D, Sampas N, Tsalenko A, Tabibiazar R, Zhang Y, Chen M, Talbi S, Ho YD, Wang J, Tsao PS, et al. Identification of endothelial cell genes by combined database mining and microarray analysis. Physiol Genomics. 2003; 13:249-262.

25. Zhou YD, Kim YP, Mohammed KA, Jones DK, Muhammad I, Dunbar DC, Nagle DG. Terpenoid tetrahydroisoquinoline alkaloids emetine, klugine, and isocephaeline inhibit the activation of hypoxia-inducible factor-1 in breast tumor cells. Journal of natural products. 2005; 68:947-950.

26. Kong HS, Lee S, Beebe K, Scroggins B, Gupta G, Lee MJ, Jung YJ, Trepel J, Neckers L. Emetine promotes von Hippel-Lindau-independent degradation of hypoxia-inducible factor-2alpha in clear cell renal carcinoma. Molecular pharmacology. 2010; 78:1072-1078.

27. Hudson CC, Liu M, Chiang GG, Otterness DM, Loomis DC, Kaper F, Giaccia AJ, Abraham RT. Regulation of hypoxiainducible factor 1alpha expression and function by the mammalian target of rapamycin. Molecular and cellular biology. 2002; 22:7004-7014.

28. Gao N, Ding M, Zheng JZ, Zhang Z, Leonard SS, Liu KJ, Shi X, Jiang BH. Vanadate-induced expression of hypoxiainducible factor 1 alpha and vascular endothelial growth factor through phosphatidylinositol 3-kinase/Akt pathway and reactive oxygen species. The Journal of biological chemistry. 2002; 277:31963-31971.

29. Chang HY, Sneddon JB, Alizadeh AA, Sood R, West RB, Montgomery K, Chi JT, van de Rijn M, Botstein D, Brown PO. Gene expression signature of fibroblast serum response predicts human cancer progression: similarities between tumors and wounds. PLoS Biol. 2004; 2:E7.

30. Mannelqvist M, Stefansson IM, Bredholt G, Hellem Bo T, Oyan AM, Jonassen I, Kalland KH, Salvesen HB, Akslen LA. Gene expression patterns related to vascular invasion and aggressive features in endometrial cancer. Am J Pathol. 2011; 178:861-871.

31. Mannelqvist M, Wik E, Stefansson IM, Akslen LA. An 18 -gene signature for vascular invasion is associated with aggressive features and reduced survival in breast cancer. PloS one. 2014; 9:e98787.

32. Lerebours F, Vacher S, Andrieu C, Espie M, Marty M, Lidereau R, Bieche I. NF-kappa B genes have a major role in inflammatory breast cancer. BMC cancer. 2008; 8:41.

33. Torri A, Beretta O, Ranghetti A, Granucci F, RicciardiCastagnoli P, Foti M. Gene expression profiles identify inflammatory signatures in dendritic cells. PloS one. 2010; 5:e9404.

34. Sancho D, Joffre OP, Keller AM, Rogers NC, Martinez D, Hernanz-Falcon P, Rosewell I, Reis e Sousa C. Identification of a dendritic cell receptor that couples sensing of necrosis to immunity. Nature. 2009; 458:899-903.
35. Brown JM, Wilson WR. Exploiting tumour hypoxia in cancer treatment. Nature reviews Cancer. 2004; 4:437-447.

36. Vinay K, AA K, Nelson F, Richard M. Robbins Basic Pathology. Philadelphia: Saunders Elsevier(8th Edition)2007; .

37. Turaka A, Buyyounouski MK, Hanlon AL, Horwitz EM, Greenberg RE, Movsas B. Hypoxic prostate/muscle PO2 ratio predicts for outcome in patients with localized prostate cancer: long-term results. International journal of radiation oncology, biology, physics. 2012; 82:e433-439.

38. Harris AL. Hypoxia - a key regulatory factor in tumour growth. Nature reviews Cancer. 2002; 2:38-47.

39. Hicks KO, Pruijn FB, Secomb TW, Hay MP, Hsu R, Brown JM, Denny WA, Dewhirst MW, Wilson WR. Use of threedimensional tissue cultures to model extravascular transport and predict in vivo activity of hypoxia-targeted anticancer drugs. Journal of the National Cancer Institute. 2006; 98:1118-1128.

40. Tannock IF. The relation between cell proliferation and the vascular system in a transplanted mouse mammary tumour. British journal of cancer. 1968; 22:258-273.

41. Koong AC, Chen EY, Giaccia AJ. Hypoxia causes the activation of nuclear factor kappa B through the phosphorylation of I kappa B alpha on tyrosine residues. Cancer Res. 1994; 54:1425-1430.

42. Yamagishi H, Olson EN, Srivastava D. The basic helixloop-helix transcription factor, dHAND, is required for vascular development. The Journal of clinical investigation. 2000; 105:261-270.

43. Jones A, Teschendorff AE, Li Q, Hayward JD, Kannan A, Mould T, West J, Zikan M, Cibula D, Fiegl H, Lee SH, Wik E, Hadwin R, et al. Role of DNA methylation and epigenetic silencing of HAND2 in endometrial cancer development. PLoS medicine. 2013; 10:e1001551.

44. Courtwright A, Siamakpour-Reihani S, Arbiser JL, Banet N, Hilliard E, Fried L, Livasy C, Ketelsen D, Nepal DB, Perou CM, Patterson C, Klauber-Demore N. Secreted frizzlerelated protein 2 stimulates angiogenesis via a calcineurin/ NFAT signaling pathway. Cancer Res. 2009; 69:4621-4628.

45. Taylor CT, Cummins EP. The role of NF-kappaB in hypoxia-induced gene expression. Annals of the New York Academy of Sciences. 2009; 1177:178-184.

46. Gu C, Yoshida Y, Livet J, Reimert DV, Mann F, Merte J, Henderson CE, Jessell TM, Kolodkin AL, Ginty DD. Semaphorin $3 \mathrm{E}$ and plexin-D1 control vascular pattern independently of neuropilins. Science. 2005; 307:265-268.

47. Roodink I, Kats G, van Kempen L, Grunberg M, Maass C, Verrijp K, Raats J, Leenders W. Semaphorin 3E expression correlates inversely with Plexin D1 during tumor progression. Am J Pathol. 2008; 173:1873-1881.

48. Forsythe JA, Jiang BH, Iyer NV, Agani F, Leung SW, Koos RD, Semenza GL. Activation of vascular endothelial growth factor gene transcription by hypoxia-inducible factor 1. Molecular and cellular biology. 1996; 16:4604-4613. 
49. Kuhn H, Weser L, Gessner C, Hammerschmidt S, Wirtz H. Release of bFGF following apoptosis and necrosis in NSCLC cells: effects on chemosensitivity to cisplatin. Oncology reports. 2005; 14:759-762.

50. Zittermann SI, Issekutz AC. Basic fibroblast growth factor (bFGF, FGF-2) potentiates leukocyte recruitment to inflammation by enhancing endothelial adhesion molecule expression. Am J Pathol. 2006; 168:835-846.

51. Cummins EP, Taylor CT. Hypoxia-responsive transcription factors. Pflugers Archiv : European journal of physiology. 2005; 450:363-371.

52. Fan Y, Mao R, Yang J. NF-kappaB and STAT3 signaling pathways collaboratively link inflammation to cancer. Protein \& cell. 2013; 4:176-185.

53. Sethi G, Shanmugam MK, Ramachandran L, Kumar AP, Tergaonkar V. Multifaceted link between cancer and inflammation. Bioscience reports. 2012; 32:1-15.

54. Yotsumoto F, Tokunaga E, Oki E, Maehara Y, Yamada H, Nakajima K, Nam SO, Miyata K, Koyanagi M, Doi K, Shirasawa S, Kuroki M, Miyamoto S. Molecular hierarchy of heparin-binding EGF-like growth factor-regulated angiogenesis in triple-negative breast cancer. Molecular cancer research : MCR. 2013; 11:506-517.

55. Spirina LV, Yunusova NV, Kondakova IV, Kolomiets LA, Koval VD, Chernyshova AL, Shpileva OV. Association of growth factors, HIF-1 and NF-kappaB expression with proteasomes in endometrial cancer. Molecular biology reports. 2012; 39:8655-8662.

56. Bonizzi G, Karin M. The two NF-kappaB activation pathways and their role in innate and adaptive immunity. Trends in immunology. 2004; 25:280-288.

57. Scholz CC, Cavadas MA, Tambuwala MM, Hams E, Rodriguez J, Kriegsheim A, Cotter P, Bruning U, Fallon PG, Cheong A, Cummins EP, Taylor CT. Regulation of IL-1beta-induced NF-kappaB by hydroxylases links key hypoxic and inflammatory signaling pathways. Proc Natl Acad Sci U S A. 2013; 110:18490-18495.

58. Weber A, Wasiliew P, Kracht M. Interleukin-1 (IL-1) pathway. Science signaling. 2010; 3:cm1.

59. Atsumi T, Singh R, Sabharwal L, Bando H, Meng J, Arima Y, Yamada M, Harada M, Jiang JJ, Kamimura D, Ogura H, Hirano T, Murakami M. Inflammation amplifier, a new paradigm in cancer biology. Cancer Res. 2014; 74:8-14.

60. Apte RN, Dotan S, Elkabets M, White MR, Reich E, Carmi Y, Song X, Dvozkin T, Krelin Y, Voronov E. The involvement of IL-1 in tumorigenesis, tumor invasiveness, metastasis and tumor-host interactions. Cancer metastasis reviews. 2006; 25:387-408.

61. Wik E, Raeder MB, Krakstad C, Trovik J, Birkeland E, Hoivik EA, Mjos S, Werner HM, Mannelqvist M, Stefansson IM, Oyan AM, Kalland KH, Akslen LA, et al. Lack of estrogen receptor-alpha is associated with epithelial-mesenchymal transition and PI3K alterations in endometrial carcinoma. Clinical cancer research : an official journal of the American Association for Cancer Research. 2013; 19:1094-1105.

62. Biswas DK, Singh S, Shi Q, Pardee AB, Iglehart JD. Crossroads of estrogen receptor and NF-kappaB signaling. Science's STKE : signal transduction knowledge environment. 2005; 2005:pe27.

63. Kalaitzidis D, Gilmore TD. Transcription factor cross-talk: the estrogen receptor and NF-kappaB. Trends in endocrinology and metabolism: TEM. 2005; 16:46-52.

64. De Bosscher K, Vanden Berghe W, Haegeman G. Crosstalk between nuclear receptors and nuclear factor kappaB. Oncogene. 2006; 25:6868-6886.

65. Engelsen IB, Stefansson IM, Akslen LA, Salvesen HB. GATA3 expression in estrogen receptor alpha-negative endometrial carcinomas identifies aggressive tumors with high proliferation and poor patient survival. American journal of obstetrics and gynecology. 2008; 199:e541-547.

66. Lax SF, Kurman RJ, Pizer ES, Wu L, Ronnett BM. A binary architectural grading system for uterine endometrial endometrioid carcinoma has superior reproducibility compared with FIGO grading and identifies subsets of advance-stage tumors with favorable and unfavorable prognosis. The American journal of surgical pathology. 2000; 24:1201-1208.

67. Bokhman JV. Two pathogenetic types of endometrial carcinoma. Gynecologic oncology. 1983; 15:10-17.

68. Mannelqvist M, Stefansson I, Salvesen HB, Akslen LA. Importance of tumour cell invasion in blood and lymphatic vasculature among patients with endometrial carcinoma. Histopathology. 2009; 54:174-183.

69. Halvorsen OJ, Oyan AM, Bo TH, Olsen S, Rostad K, Haukaas SA, Bakke AM, MarzolfB, Dimitrov K, Stordrange L, Lin B, Jonassen I, Hood L, et al. Gene expression profiles in prostate cancer: association with patient subgroups and tumour differentiation. Int J Oncol. 2005; 26:329-336.

70. Rostad K, Mannelqvist M, Halvorsen OJ, Oyan AM, Bo TH, Stordrange L, Olsen S, Haukaas SA, Lin B, Hood L, Jonassen I, Akslen LA, Kalland KH. ERG upregulation and related ETS transcription factors in prostate cancer. Int $\mathrm{J}$ Oncol. 2007; 30:19-32.

71. Tusher VG, Tibshirani R, Chu G. Significance analysis of microarrays applied to the ionizing radiation response. Proc Natl Acad Sci U S A. 2001; 98:5116-5121.

72. Engelsen IB, Mannelqvist M, Stefansson IM, Carter SL, Beroukhim R, Oyan AM, Otte AP, Kalland KH, Akslen LA, Salvesen HB. Low BMI-1 expression is associated with an activated BMI-1-driven signature, vascular invasion, and hormone receptor loss in endometrial carcinoma. British journal of cancer. 2008; 98:1662-1669.

73. Guyon I, Elisseeff A. An Introduction to Variable and Feature Selection. Journal of Machine Learning Research. 2003; 3:1157-1182.

74. Hu Z, Fan C, Livasy C, He X, Oh DS, Ewend MG, Carey LA, Subramanian S, West R, Ikpatt F, Olopade OI, van de Rijn M, 
Perou CM. A compact VEGF signature associated with distant metastases and poor outcomes. BMC Med. 2009; 7:9.

75. Bild AH, Yao G, Chang JT, Wang Q, Potti A, Chasse D, Joshi MB, Harpole D, Lancaster JM, Berchuck A, Olson JA Jr., Marks JR, Dressman HK, et al. Oncogenic pathway signatures in human cancers as a guide to targeted therapies. Nature. 2006; 439:353-357.
76. Lamb J, Crawford ED, Peck D, Modell JW, Blat IC, Wrobel MJ, Lerner J, Brunet JP, Subramanian A, Ross KN, Reich M, Hieronymus H, Wei G, et al. The Connectivity Map: using gene-expression signatures to connect small molecules, genes, and disease. Science. 2006; 313:1929-1935. 